\title{
Anti-HER2 vaccines: new prospects for breast cancer therapy
}

\author{
Maha Zohra Ladjemi • William Jacot • \\ Thierry Chardès · André Pèlegrin • \\ Isabelle Navarro-Teulon
}

Received: 12 October 2009/ Accepted: 11 May 2010/Published online: 8 June 2010

(C) The Author(s) 2010. This article is published with open access at Springerlink.com

\begin{abstract}
Each year, breast cancer accounts for more than 400,000 new cancer cases and more than 130,000 cancer deaths in Europe. Prognosis of nonmetastatic breast cancer patients is directly related to the extent of the disease, mainly nodal spreading and tumor size, and to the molecular profile, particularly HER2 over-expression. In patients with HER2over-expressing tumors, different studies have shown cellular and/or humoral immune responses against HER2 associated with a lower tumor development at early stages of the disease. These findings have led to the hypothesis that the generation of an anti-HER2 immune response should protect patients from HER2-over-expressing tumor growth. Taken together with the clinical efficiency of trastuzumab-based anti-HER2 passive immunotherapy, these observations allowed to envisage various vaccine strategies against HER2. The induction of a stable and strong immunity by cancer vaccines is expected to lead to establishment of immune memory, thereby preventing tumor recurrence. However, an immunological tolerance against HER2 antigen exists representing a barrier to effective vaccination against this oncoprotein. As a consequence, the current challenge for vaccines is to find the best conditions to break this immunological tolerance. In this review, we will discuss the different anti-HER2 vaccine strategies currently developed; considering the strategies having reached the clinical
\end{abstract}

M. Z. Ladjemi · T. Chardès · A. Pèlegrin

I. Navarro-Teulon $(\bowtie)$

IRCM, Institut de Recherche en Cancérologie de Montpellier, INSERM U896, Université Montpellier1,

CRLC Val d'Aurelle Paul Lamarque,

34298 Montpellier, France

e-mail: isabelle.teulon@valdorel.fnclcc.fr

W. Jacot

CRLC Val d'Aurelle Paul Lamarque, 34298 Montpellier, France phases as well as those still in preclinical development. The used antigen can be either composed of tumoral allogenic cells or autologous cells, or specific to HER2. It can be delivered by dendritic cells or in a DNA, peptidic or proteic form. Another area of research concerns the use of antiidiotypic antibodies mimicking HER2.

Keywords Breast cancer · HER2 - Vaccine

\section{Introduction}

The HER2 receptor is a tumor-associated antigen, which is normally present during embryonic development and, in adult life, is over-expressed by malignant cells. Specifically, $15 \%$ of invasive breast cancers, $54-100 \%$ of colorectal cancers, $25 \%$ of ovarian cancers, $17-82 \%$ of pancreatic cancers and $34 \%$ of prostate cancers [1-3] overexpress HER 2 and this feature is correlated with greater tumor aggressiveness, increased risk of recurrence and poor prognosis [4]. Since HER2 is over-expressed at the cell surface of tumor cells, it represents a good target for anti-cancer immunotherapy [5].

Over the past few years, monoclonal antibodies (mAbs) as well as tyrosine kinase inhibitors that target HER2 have been developed. Recent results with anti-HER2 mAbs, such as trastuzumab (Herceptin ${ }^{\circledR}$, Roche, Switzerland), validated the use of passive immunotherapy for the treatment of cancer. Trastuzumab is a humanized $\mathrm{mAb}$ directed against the extracellular domain (ECD) of HER2 and its use, in combination with chemotherapy, has been approved by the FDA in 1998 for metastatic HER2 over-expressing breast cancer [6]. However, a major limit of immunotherapy with trastuzumab is the development of drug resistance usually within 1 year from the beginning of the treatment 
in the metastatic setting [7, 8]. Additionally, the risk of cardiac toxicity, especially in patients previously treated with anthracyclines, may limit the use of trastuzumab $[9,10]$.

Since 1994, different studies have shown the presence of cellular and/or humoral immune responses against HER2 in patients with HER2 over-expressing tumors [5, 11, 12]. As shown in a preclinical model, such immune responses can be associated with slower tumor development at the early stages of the disease [13]. These observations, together with the reports about the efficiency of trastuzumab-based antiHER2 passive immunotherapy, motivated the development of various anti-HER2 vaccine strategies with different limitations (Table 1). Indeed, the use in patients of a vaccine that induces or stimulates a pre-existing anti-HER2 immune response offers several advantages (Table 1) when compared with passive immunotherapy with trastuzumab: (1) fewer iterative injections, (2) potentially broader use in patients expressing different levels of HER $2(+1$ to +3 by immunohistochemistry, IHC) and (3) establishment of a memory immune response capable of preventing disease recurrence.
However, immunological tolerance against HER2 does exist and it represents a major obstacle to effective vaccination against this oncoprotein. Accordingly, the current challenge for vaccines is to find the best conditions to break such immune tolerance without inducing autoimmune reactions that would be deleterious for the healthy tissues [14], particularly the myocardium.

Vaccines evaluated in clinical trials (Table 2) are made of tumoral allogeneic or autologous cells or are HER2specific. They can be delivered using dendritic cells (DCs) or in a DNA, peptidic or proteic form (Table 2). A more recent vaccine strategy is represented by the use of antiidiotypic antibodies (anti-Id Abs) that mimic HER2 and are usually injected in combination with vaccine adjuvants or immune-stimulating cytokines.

Considering the existing immunological tolerance against HER2, we will discuss the different anti-HER2 vaccine strategies that are currently developed and have been or are assessed in clinical trials as well as those which are still at the preclinical stage. We will also comment on how anti-HER2 vaccines can be combined with other strategies to improve the clinical responses.

Table 1 Vaccination strategies: advantages versus disadvantages

\begin{tabular}{|c|c|c|}
\hline Vaccination strategy & Advantages & Disadvantages \\
\hline \multirow[t]{4}{*}{ Whole tumor cells } & $\begin{array}{l}\text { Complete Ag pool of an individual tumor (including } \\
\text { Ags that have not been identified yet) }\end{array}$ & Must be made individually for each patient \\
\hline & $\begin{array}{l}\text { Activation of a polyclonal and more effective } \\
\text { immune response }\end{array}$ & $\begin{array}{l}\text { Lack of co-stimulatory molecules on solid } \\
\text { tumor cells }\end{array}$ \\
\hline & \multirow{2}{*}{$\begin{array}{l}\text { The immune system rather than the vaccinologist } \\
\text { selects the most immunogenic tumor-specific Ags }\end{array}$} & Immune response difficult to monitor \\
\hline & & $\begin{array}{l}\text { Induction of auto-immunity in the presence } \\
\text { of adjuvant }\end{array}$ \\
\hline \multirow[t]{3}{*}{ Dendritic cells (DCs) } & $\begin{array}{l}\text { Presentation of the vaccine Ags to other cell types of } \\
\text { the immune system }\end{array}$ & Must be made individually for each patient \\
\hline & $\begin{array}{l}\text { Expression of high levels of HLA complexes and } \\
\text { co-stimulatory molecules }\end{array}$ & Generation of DCs technically challenging \\
\hline & Stimulation of both naive and memory $\mathrm{T}$ cells & Money- and time-consuming treatment \\
\hline \multirow[t]{3}{*}{ DNA } & Easy and cheap to produce and purify & $\begin{array}{l}\text { DNA integration into the cell genome } \\
\text { potentially promoting malignancy }\end{array}$ \\
\hline & Require no special handling or storage conditions & \multirow{2}{*}{$\begin{array}{l}\text { Less effective than peptide vaccines in } \\
\text { inducing } \mathrm{CD} 8^{+} \mathrm{T} \text { cell response }\end{array}$} \\
\hline & $\begin{array}{l}\text { Elicitation of both } \mathrm{CD}^{+} \text {and } \mathrm{CD} 4^{+} \text {immune } \\
\text { responses as well as humoral responses }\end{array}$ & \\
\hline \multirow[t]{4}{*}{ Peptides } & Easy to manufacture & $\begin{array}{l}\text { Immune response limited to one or few } \\
\text { epitopes }\end{array}$ \\
\hline & Strong $\mathrm{CD}^{+} \mathrm{T}$ cell response & HLA restriction \\
\hline & Known sequence and biochemistry & Degradation in the absence of adjuvant \\
\hline & $\begin{array}{l}\text { Allow specific monitoring of the patient's immune } \\
\text { response }\end{array}$ & \\
\hline \multirow[t]{3}{*}{ Anti-idiotypic antibodies } & Unrestricted HLA population & \multirow[t]{3}{*}{ Human anti-mouse antibody response } \\
\hline & $\begin{array}{l}\text { Allow effective vaccination against non-protein Ags } \\
\text { and poorly immunogenic Ags }\end{array}$ & \\
\hline & Elicit both humoral and cellular immune response & \\
\hline
\end{tabular}




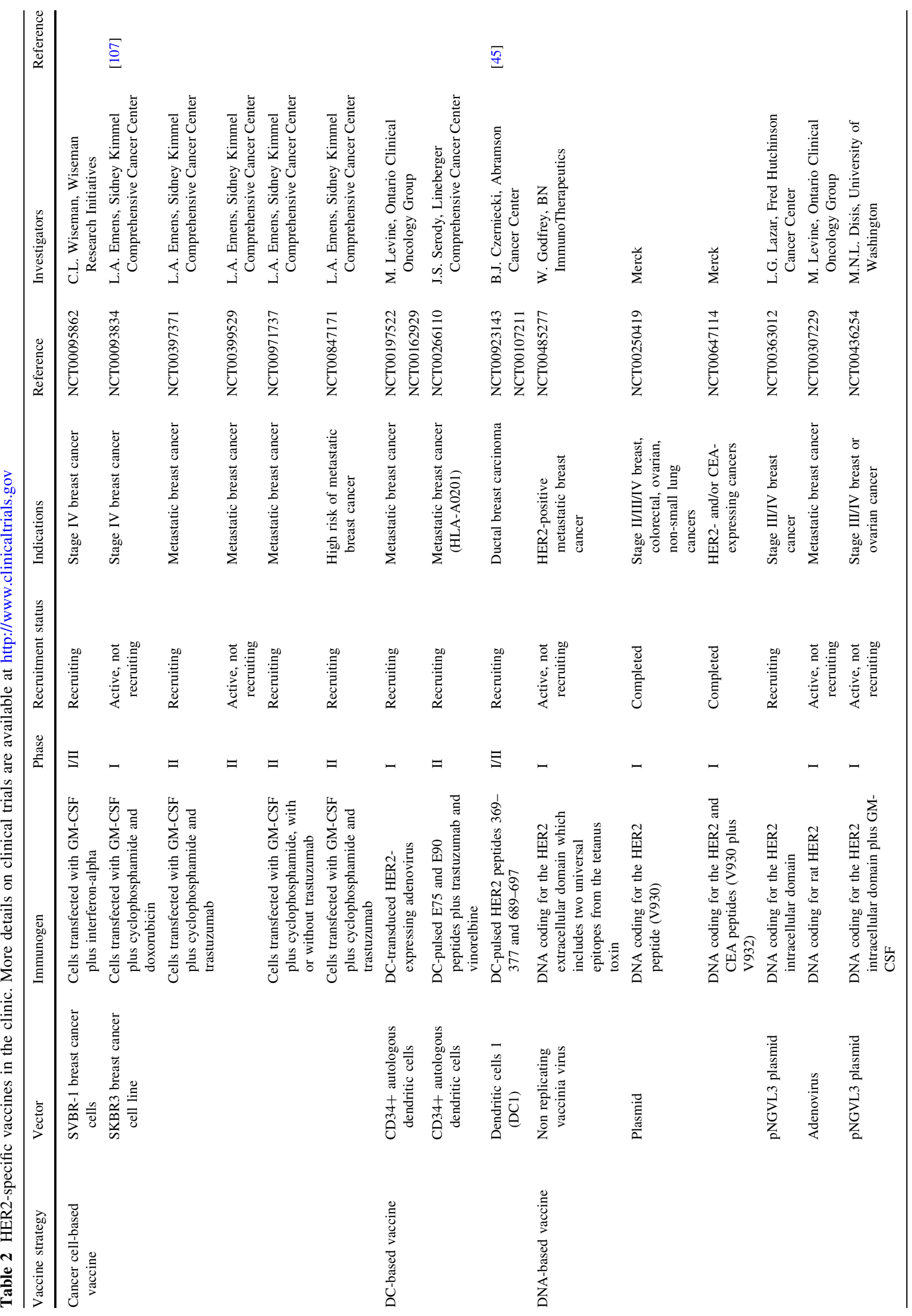




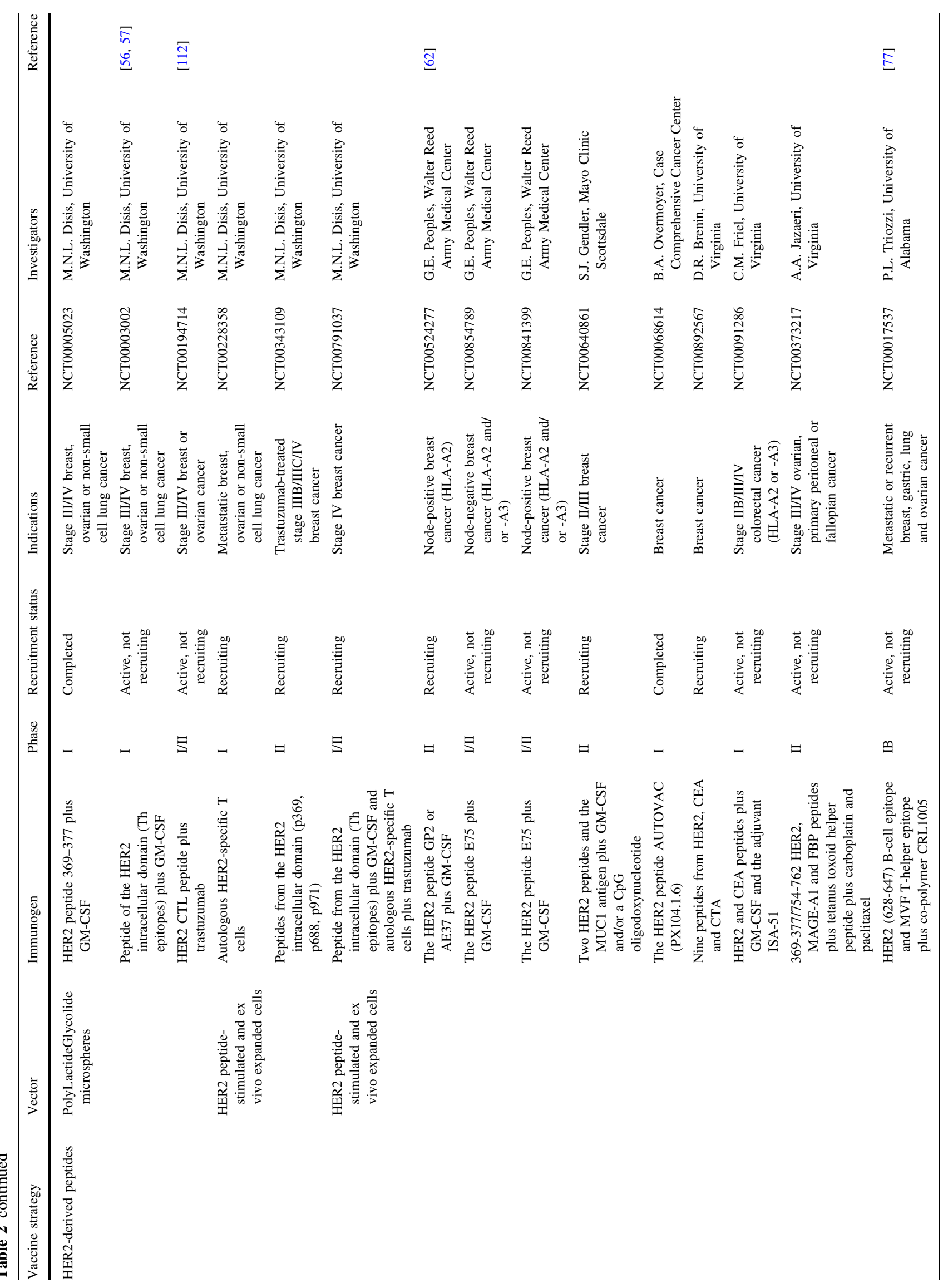




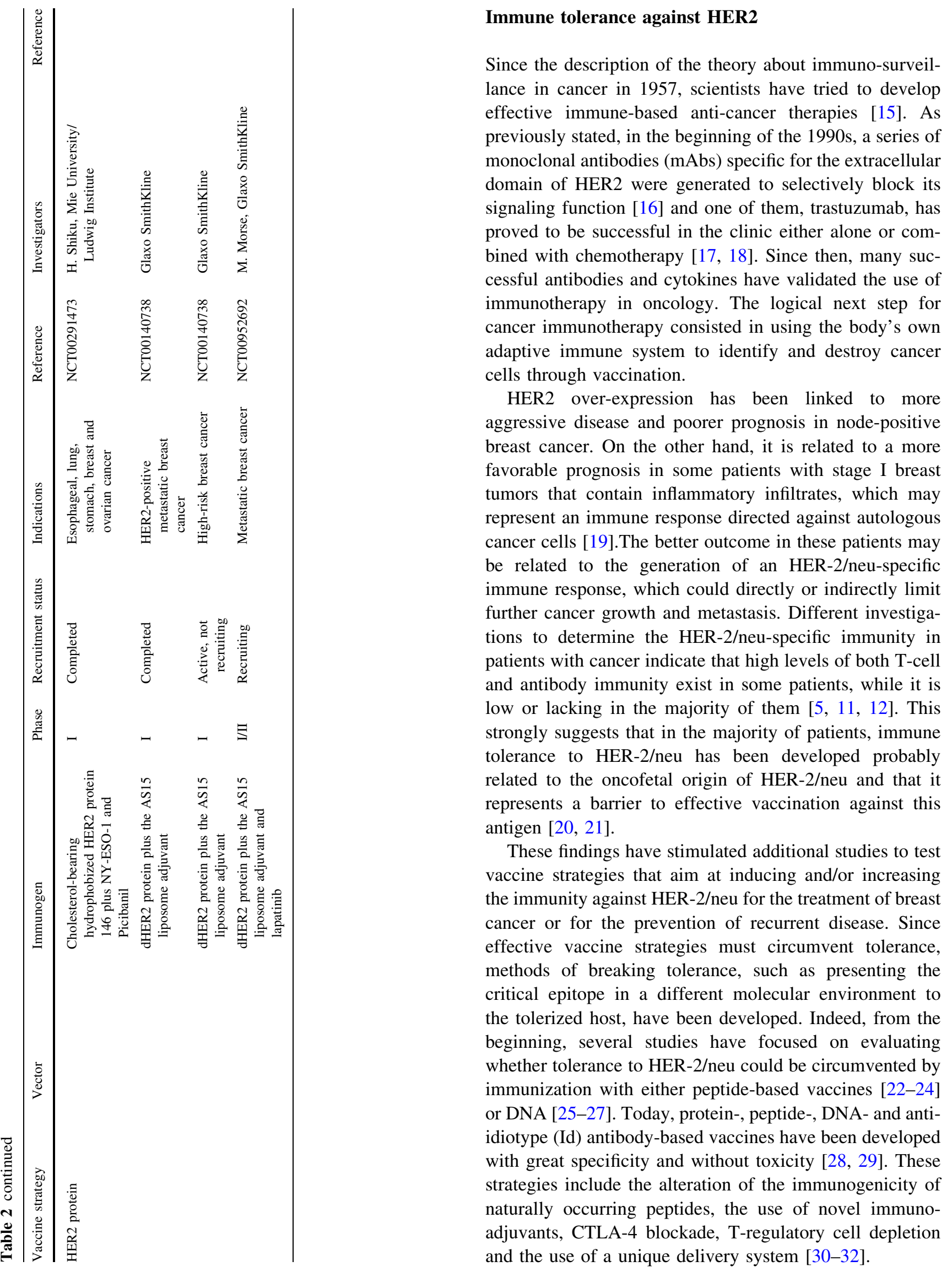




\section{Vaccines based on whole cells}

Tumor cells

This type of vaccine has the theoretical advantage of providing a complete mixture of tumor antigens to the patient's immune system to develop an effective immune response. However, the induction of an antigen-specific immune response depends on the presence of non-specific co-stimulatory signals provided by antigen presenting cells (APCs) to activate T cells. Since most solid tumors do not express these co-stimulatory molecules, they are unable to provide all the signals necessary for T-cell activation. Thus, to confer an immuno-stimulant potential to tumor cell-based vaccines, genes encoding co-stimulatory factors, such as CD80 or cytokines, have been introduced in these vaccines [33, 34].

More recently, Kim PS et al. [35] have demonstrated in a preclinical model that combined administration in mice of HER2/neu-specific mAb and an HER-2/neu-expressing, GM-CSF-secreting whole tumor cell vaccine enhanced the induction of neu-specific $\mathrm{CD}^{+} \mathrm{T}$ cells through Fc-mediated activation of dendritic cells.

\section{Autologous cells}

Recently, a phase I clinical study of 18 patients with metastatic breast cancers, which over-express HER2, evaluated the toxicity and the immune response induced by lapuleucelT (APC8024), an autologous active cellular immunotherapy [36]. This vaccine was prepared from peripheral blood mononuclear cells (PBMCs), including APCs, which had been activated in vitro with the recombinant fusion protein BA7072 composed of the intra- and extracellular domains (ICD and ECD, respectively) of HER2 fused to GM-CSF. The vaccine was well tolerated and a significant anti-HER2 cellular response was observed. One patient had a partial tumor response for 6 months and disease stabilization for 1 year was observed in three other patients [36]. These results are encouraging and further trials should be performed to confirm the clinical benefits of lapuleucel-T. Other clinical trials have been conducted using SVBR-1 or SKBR-3 breast cancer cells (Table 2).

\section{Dendritic cells}

The use of DCs as a vaccine strategy has the theoretical advantage of promoting the presentation of the vaccine antigens to other cell types of the immune system.

\section{Experimental work}

A preclinical study demonstrated that immunization with DCs transfected with an adenovirus encoding the HER2 protein delayed the onset of spontaneous HER2/neu over-expressing mammary tumors in BALB/c transgenic mice [37].

Chen et al. [38] have shown that administration of DCs transfected with an adenovirus encoding both HER2 and IL-12 could induce tumor protection in FVB mice challenged with syngeneic HER2 over-expressing tumor cells and that both $\mathrm{CD}^{+}{ }^{+}$and $\mathrm{CD}^{+}{ }^{+} \mathrm{T}$ lymphocytes (TL) were necessary to elicit this response. Similar results were obtained with DCs transfected with an adenovirus encoding HER2 and TNF $\alpha$ [39].

In 2008, Sas et al. [40] used (RGD) AdVneu, a recombinant adenovirus that encodes the HER2/neu protein and the arg-gly-asp (RGD) motif. The addition of the RGD motif in the construct was reported to efficiently increase expression of HER2/neu. The authors transfected DCs with (RGD) AdVneu [(DCneu2 cells) or AdVneu alone (DCneu1 cells)] and then evaluated the anti-HER2 cellular and humoral responses as well as the anti-tumor effect [41]. In DCneu2 cells, HER2/neu expression was more than eight times higher than in DCneul cells. Similarly, the CTL and humoral responses induced by DCneu2 vaccination were more important than those induced by DCneu1 vaccination. Immunization of FVB mice with the DCneu2-based vaccine protected $100 \%$ of the animals that were transplanted with a syngeneic tumor cell line, which over-expresses HER2 [41]. In addition, the same authors previously reported in a sideby-side study that a vaccine based on DCs transfected with an adenovirus encoding HER2 was more efficient than the DNA-based HER2 vaccine [42].

Another preclinical study tested the effectiveness of syngeneic DCs transfected with a construct in which HER2 ECD is fused with the transduction domain of the Tat protein [43]. Mice immunized intra-peritoneally (ip) with these DCs developed tumors of significantly smaller size than non-immunized animals or mice immunized with DCs transfected only with the Tat transduction domain. The authors also demonstrated that the anti-tumor effect was due to a $\mathrm{CD}^{+}$and $\mathrm{CD}^{+} \mathrm{T}$ response [43].

\section{Clinical trials}

Three clinical trials are currently ongoing and they all use loaded DCs (Table 2). Among them, one included six patients with breast or ovarian cancer immunized subcutaneously with DCs loaded with two peptides derived from HER2: p369 [amino acids (aa) 369-377] and p654 (aa 654-662) [44]. After three immunizations, two patients developed p369-specific circulating TL, which efficiently inhibited growth of HER2-positive cancer cells in vitro. Moreover, one of the two patients was stabilized for 8 months, while having been in progress before the enrollment in the vaccination trial. 
More recently, 13 patients with HER2 over-expressing ductal in situ carcinoma were injected with DCs loaded with a mixture containing 6 HLA-I- and HLA-II-restricted peptides (i.e., 3 HER2 ECD-derived peptides and 3 HER2 ICD-derived peptides) once a week for 4 weeks before surgery [45]. Immunized patients developed a specific immune response against the peptides and presented high levels of $\mathrm{CD}^{+}{ }^{+} \mathrm{TL}$ secreting IFN $\gamma(85 \%)$ as well as $\mathrm{CD} 8^{+}$ TL (80\%). In surgical biopsies of seven of these patients, a significant reduction of HER2 expression was observed that could often be correlated with a surgically measured tumor size smaller than the pre-therapeutic size predicted using MRI [45].

\section{DNA-based vaccines}

\section{Experimental work}

Wei et al. [46, 47] have developed several DNA vaccines that encode a modified human HER2 protein without tyrosine kinase activity. The three main constructs were (1) pE2A that encodes a full-length HER2 in which Lys753 has been substituted by Ala to remove the ATP-binding Lys residue, (2) pE2TM that encodes the HER2 signal peptide, extracellular and transmembrane domains but not the intracellular one and (3) psecE2 that encodes the $\mathrm{N}$-terminal portion (aa 1-505) of ECD as a secreted protein. All of them induced both cellular and humoral immune responses leading to in vivo tumor protection. On the other hand, immunization of mice with another construct, pcytE2 (i.e., HER2 without signal peptide), elicited only a $\mathrm{CD} 8^{+}$ TL response [27]. These first pre-clinical studies used DNA vaccines alone injected intramuscularly (im). Subsequently, the GM-CSF sequence was added to the constructs to improve the immune response and this novel generation of DNA vaccines was injected by electroporation to enhance transgene expression [48-50]. These vaccines elicited a significant and specific anti-HER2 immunity and tumor rejection in wild-type mice challenged with syngeneic cancer cells or in HER2 transgenic mice.

Similarly, Rovero et al. [51] reported that the DNA vaccine p185, which encodes HER2 ECD and the transmembrane domain, was effective in inhibiting carcinogenesis in a transgenic mouse model.

Intramuscular injection of either a DNA plasmid or an adenoviral vector both encoding HER2 elicited a specific anti-HER2 cellular immune response in transgenic BALB/c mice that develop spontaneous HER2/neu-expressing mammary tumors. However, the adenoviral vector was the only one capable of inducing a specific anti-HER2 humoral response and was more effective than the DNA plasmid vaccine [52].
Recently, a study examined the ability of a novel agonist of the Toll-like receptor 9, called immuno-modulatory oligonucleotide (IMO), to enhance the effects of an HER2 DNA electroporation/adenovirus (DNA-EP/Ad) vaccine [53]. The authors demonstrated that the combination of this vaccine with IMO stimulated a stronger anti-tumoral response associated with antibody-dependent cellular cytotoxicity $(\mathrm{ADCC})$ in immunized mice.

The genetic regulation of the response to an anti-cancer vaccine has been investigated by Jacob et al. The authors immunized three different mouse strains with the same antiHER2 DNA-based vaccine and reported that both the amplitude of the induced immune response and the vaccine efficacy depended on the genetic background of the mice. They also showed that the positive effect of the depletion of T-regulatory cells (Treg) on the anti-tumor immunity depended on the genetic background of the immunized mice [54]. Furthermore, and significantly, the same research team reported that tumor regression induced by Treg depletion and anti-HER2 DNA vaccination of tolerant mice can exacerbate autoimmunity, which would probably deserve close monitoring during immunotherapy trials [55].

\section{Clinical trials}

The anti-HER2 DNA-based vaccination strategy has now entered the clinical phase. Indeed, five phase I clinical trials are under way (Table 2). Among them, one is conducted by Merck Laboratories and evaluates the toxicity and efficiency of the DNA vaccine V930, which encodes HER2 and CEA (carcinoembryonic antigen). The recruitment of patients with stage II, III or IV breast, ovary, colon or non-small cell lung cancers that express HER2 and/or CEA began in October 2005 and inclusion is now completed. Another phase I clinical trial is conducted by the Bavarian Nordic's subsidiary BN Immunotherapeutics (BNIT) and began in June 2007. The recruited patients have metastatic, HER2 over-expressing breast cancer and went through one or two lines of chemotherapy associated or not with trastuzumab. The vaccine used in this study is the MV-BN-HER2 formed by a non-replicating viral vector encoding a truncated form of HER2 protein (without its ICD) and two universal $\mathrm{T}$ epitopes of the tetanus toxin used to boost the immune system. Three other clinical trials, using either DNA coding for the HER2 intracellular domain cloned into the pNGVL3 plasmid or adenovirusinserted rat HER2 DNA are active or recruiting (Table 2).

\section{Peptide-based vaccines}

The largest part of the literature data about anti-HER2 vaccination strategies concerns vaccines based on peptides 
derived from this tumor antigen. Numerous clinical trials have been conducted using various peptide vaccine preparations (Table 2). Some of them have been completed, while others are currently active or under recruitment.

Peptide vaccines inducing predominantly a cellular immune response

\section{Multi-peptide vaccines}

Several clinical studies have assessed the efficacy of vaccines composed of peptides derived from HER2 ICD and ECD (Table 2).

Among them, a phase I clinical trial involving 64 patients with HER 2 over-expressing breast, ovarian or non-small cell lung cancer [24] evaluated the efficiency of three vaccines, each one containing three different peptides derived from HER2 T-helper epitopes: (1) ECD-derived peptides: p42 (aa 42-56), p98 (aa 98-114) and p328 (aa 328-345), (2) ICDderived peptides: p776 (aa 776-790), p927 (aa 927-941) and p1,166 (aa 1,166-1,180) or (3) peptides derived from the two domains: p369 (aa 369-386), p688 (aa 688-703) and p971 (aa 971-984). Each vaccine dose (500 $\mu \mathrm{g}$ of each peptide in combination with $100 \mu \mathrm{g}$ of GM-CSF) was administered intradermally. After vaccination, $92 \%$ of patients developed a T-cell response specific to at least one of the three peptides present in the vaccine. Most patients also developed a T-cell response against one of the HER2 domains: $26 \%$ against the ECD and 63\% against the ICD. The anti-peptide or anti-HER2 immunity was still detectable in $38 \%$ of patients 12 months after the last vaccination [24]. However, no correlation could be established between the development of the anti-peptide response and the development of the anti-HER2 immune response. Interestingly, the authors also reported that $84 \%$ of patients showed a T-cell response specific to a peptide not contained in the vaccine formulation (epitope spreading). The humoral immune response elicited by these vaccines was also analyzed in 35 patients with HER2- over-expressing breast, ovary or nonsmall cell lung cancer enrolled in another phase I clinical trial [56]. As much as $60 \%$ of patients developed humoral immunity directed against at least one of the three peptides contained in the vaccine, but only $29 \%$ of patients developed anti-HER2 humoral immunity and among them 70\% showed epitope spreading. Compared with the anti-HER2 cellular response [24], the humoral response was less important [57] and this difference could be due to the fact that the vaccines were derived from HLA-restricted T epitopes and/or that the vaccine adjuvant GM-CSF promotes predominantly a cellular response of Th1 type, characterized by IFN $\gamma$ secretion [58].

Although the aim of vaccination clinical trials is to establish or strengthen a pre-existing immune response, these two studies have shown concomitant epitope spreading, which may constitute a predictive marker of immune response and clinical benefit in vaccination trials or more generally for immunotherapy in oncology [59]. Recently, Disis et al. [60] carried out a long-term follow-up (average period: 2.7 years) of the results of three antiHER2 vaccination clinical trials and showed that the development of an HER2-specific T-cell response together with epitope spreading could be correlated with clinical benefit. Other studies should be conducted to better assess these findings.

Another phase I clinical study evaluated the third vaccine formulation described above (derived from both ECD and ICD of HER2: p369, p688 and p971) in 19 HLA-A2 positive patients with HER2 over-expressing breast or ovarian cancer [58] (Table 2). Of the patients, 83\% developed a T-cell immunity directed against at least one of the three immunizing peptides. In addition, peptidespecific $\mathrm{T}$ cells had a cytotoxic effect on HER2-positive tumor cells. $\mathrm{CD} 8^{+} \mathrm{TL}$ immunity was still detectable 1 year after the last vaccination in five patients. Concerning the anti-HER2 cellular response, $28 \%$ of patients developed a response against ICD and 50\% against ECD. A phase I/II clinical trial is currently evaluating this tri-peptide vaccine in combination with trastuzumab [61]. The patients included in this trial are HLA-A2 positive, with HER2 overexpressing, stage IV breast or ovarian cancer and they are stabilized or without apparent disease. Among the ten patients whose immune response was analyzed, five developed a T-cell response specific to one of the peptides and/or the native form of HER2. This study, although preliminary and for which the long-term follow-up results have not yet been published, proves that it is possible to vaccinate and to induce an anti-HER 2 response in patients who are treated with trastuzumab. It is important to note that, at the time of communication of the results, 2 of the 14 patients of this study presented with asymptomatic impaired ventricular function of grade 2 according to the NCI-CIC scale of toxicity (from 54 to $49 \%$ in one subject and from 64 to $45 \%$ in the other). Consequently, it is not possible at the moment to conclude about the safety, and particularly about the possible cardiac toxicity, of this therapeutic combination.

On the other hand, the results of the first phase I clinical trial, with the hybrid anti-HER2 AE37 peptide, have been published [31]. This vaccine is composed of the MHC-II peptide of HER2 (aa 776-779) alone (AE36) or fused on the C-terminal part with a sequence of 4 aa (LRMK) called "li-Key" (AE37). This sequence can interact with MHC-II molecules and increase $\mathrm{CD} 4^{+} \mathrm{TL}$ response. The vaccine was tested in 15 patients with node-negative breast cancer in remission. The vaccine was administered intradermally at three different doses $(100,500$ and $1000 \mu \mathrm{g})$ in 
combination with different doses of GM-CSF (from 0 to $250 \mu \mathrm{g}$ ) once a month for 6 months. Vaccination with AE37, with or without GM-CSF, induced a dose-dependent cellular immune response specific to AE37 and also, albeit to a lesser extent, to AE36. According to the authors, this is the first study demonstrating the effectiveness of a peptide vaccine in the absence of an adjuvant [31]. The optimal therapeutic doses were determined at $500 \mu \mathrm{g}$ of AE37 in combination with $62.5 \mu \mathrm{g}$ of GM-CSF.

\section{E75 peptide}

Among the HER2 peptides described above, p369 (aa 369377), which is derived from ECD and is also known as E75, has been evaluated in several preclinical and clinical studies and is currently assessed in a randomized multicenter phase III clinical trial [62] (Table 2). Preclinical studies with E75 have demonstrated its ability to induce a specific immune response mediated by CTLs [63, 64]. Three clinical studies used E75 as an anti-HER2 vaccine in combination with incomplete Freund's adjuvant (IFA) or GM-CSF and showed that vaccination induced a specific anti-peptide immune response with no associated toxicity [65-67].

Peoples et al. conducted two phase II clinical trials in patients in remission after breast cancer but considered to be at high risk of recurrence. At the time of inclusion, patients had no apparent disease and had completed the adjuvant cycles of conventional therapies (surgery, chemotherapy and radiotherapy when indicated). Indeed, nowadays, the therapeutic challenge remains the prevention of tumor recurrence for which curative options are poor. The first trial recruited patients with node-positive breast cancer and the second one included also patients with node-negative breast cancer (Table 2).

In the first study, since E75 binds to the HLA-A2 allele, 29 HLA-A2 negative patients received a placebo and 24 HLA-A2 positive patients not previously treated using adjuvant trastuzumab therapy were vaccinated [68]. The vaccine was administered intradermally once a month for 6 months and the injected mixture consisted of different doses of E75 peptide (from 100 to 1,000 $\mu \mathrm{g}$ ) in combination with $250 \mu \mathrm{g}$ of GM-CSF. All vaccinated patients developed E75-specific CD8 ${ }^{+}$TL clones that could lyse HER2 positive tumor cells. Concerning the clinical benefit after a median follow-up of 22 months, disease-free survival was $85.7 \%$ in immunized patients versus $59.8 \%$ in patients with placebo. At the same time, the reported recurrence rate was $8 \%$ in the HLA-A2 vaccinated group against $21 \%$ for the non-vaccinated patients. This clinical trial has shown that immunization with E75 of nodepositive breast cancer patients is correlated with higher disease-free survival and significantly lower recurrence rates.
The results of the second phase II clinical trial on nodenegative patients has not been published, but they might be inferred from the results of the two phase III clinical trials that evaluated the same vaccine formulation in nodenegative and -positive patients with breast cancer in remission not previously treated using adjuvant trastuzumab therapy [69]. In total, 177 patients were included in these two trials, the largest study to date in the field of adjuvant immunization in breast cancer. Vaccination with E75 induced or significantly increased peptide-specific $\mathrm{CD} 8^{+} \mathrm{TL}$ immunity after the third or fourth immunization in $65 \%$ of patients, but this immunity was maintained in only $43 \%$ of them, 6 months after the last vaccination. The majority of patients also presented epitope spreading against GP2, another peptide-based vaccine candidate derived from HER2. Moreover, fewer circulating tumor cells were observed in vaccinated patients, which could be a predictive marker of the effectiveness of vaccination. Interestingly, a significant reduction in the number of $\mathrm{CD}^{+}$ $\mathrm{CD} 25^{+}$Treg cells and of the rate of activation of $\mathrm{CD} 4^{+}$ $\mathrm{CD} 25^{+} \mathrm{CD} 9^{+}$Treg cells was reported in vaccinated patients [70]. Indeed, it has been previously shown that Treg cells are involved in reducing the effectiveness of the immune responses directed against tumor tissues and that removal of $\mathrm{CD} 25^{+} \mathrm{CD} 4^{+}$Treg cells can abrogate immunological unresponsiveness [71]. A significant advantage of the vaccine in terms of recurrence rate $5.6 \%$ in vaccinated patients versus $14.2 \%$ in those treated with placebo) was demonstrated after 18 months follow-up. At the time of the latest analysis, with a follow-up of 26 months, the results were still in favor of the vaccine, but the difference between the two groups in terms of recurrence rate and survival was no longer statistically significant. The authors hypothesized that the vaccine induced a $\mathrm{CD} 8^{+} \mathrm{TL}$ immune response unable, by itself, to lead to the establishment of a memory immune response [69].

Benavides et al. [72] have studied the impact of HER2 expression level on the response to the E75 vaccine. They demonstrated that most patients responded immunologically and seemed to benefit from vaccination independently from the level of HER2 expression of their cancer. However, the low expressors (specifically, IHC $1+$ patients) had more robust immune responses and thus might derive the greatest clinical benefit from vaccination with E75 [72].

In conclusion, the clinical trials with E75 have demonstrated that it can lower the recurrence rate when used in an adjuvant setting. However, this vaccine needs to be improved, particularly its ability to develop a long-term immune vigilance. Using a multi-epitope vaccine or combining this peptide with another anti-HER2 immunotherapy, such as trastuzumab, could possibly answer this issue.

Indeed, a preclinical study showed that pretreatment of HER2-over-expressing breast cancer cells with trastuzumab 
increased the specific cytotoxicity of CTLs stimulated by E75 and GP2 [73]. These findings could be explained by a higher internalization and faster recycling rates of HER following trastuzumab binding. Similar results were obtained in human breast cancer cells with very low HER2 expression, leading to consider trastuzumab as a vaccinepotentiating agent in these tumors. In addition, PBMCs of E75-vaccinated patients showed higher cytotoxicity in breast cancer cells pretreated with trastuzumab than in untreated ones [73]. These results provide a proof of concept for the potential benefit of using a combination of immunotherapeutic strategies.

Finally, Benavides et al. [72] have recently demonstrated that in a subset of high expressor patients (IHC $3+$ ), who received trastuzumab before vaccination, such therapeutic combination was safe and immunologically beneficial. However, these results need to be confirmed in a wider population, since this study concerned only seven patients, precluding all prognosis analyses.

\section{GP2 peptide}

GP2 is a 9 aa HLA-A2-restricted peptide derived from the transmembrane domain of HER2 (aa 654-662) [5]. Despite its low affinity to HLA-A2 [5], in vitro studies have shown that it is as effective as E75 at inducing a CTL response, suggesting that it might be more immunogenic than E75 [74]. A phase I clinical study using GP2 in combination with GM-CSF is ongoing. The next step will probably be a clinical trial to evaluate the effects of a multi-epitope antiHER2 vaccine, which combines both E75 and GP2 (Table 2).

\section{Other peptides}

Very recently, Lekka et al. developed peptide vaccines that stimulate the tumor antigen-specific T-lymphocyte response against frequent cancers. In particular, vaccination with the peptide QIAKGMSYL, an epitope, which is naturally presented by various HER2-positive cancer cell lines, was immunogenic in HHD transgenic mice and was effective against established tumors, inducing complete regression in $50 \%$ of mice [75].

Peptide vaccines predominantly inducing a humoral immune response

\section{Experimental work}

Other approaches have focused on the identification of HER2 B cell-specific epitopes and their development for use as anti-HER 2 peptide-based vaccines. Research in this area is still at the preclinical stage.
Using phage display technology, Yip et al. [76] identified HER2-specific epitopes recognized by three different anti-HER2 mAbs. One of these mAbs has an anti-proliferative effect in vitro against HER2-expressing tumor cells. $\mathrm{BALB} / \mathrm{c}$ mice immunized with the epitope specific for this $\mathrm{mAb}$ developed not only an anti-peptide, but also an antiHER2 B-cell immune response. In addition, sera from these mice could inhibit in vitro the growth of HER2-overexpressing BT474 breast cancer cells.

Similarly, the identification of B-cell epitopes specific to HER2 ECD using a modeling software and immunization of rabbits with the corresponding peptides elicited antipeptide and anti-HER2 humoral responses [22]. Immunization of transgenic mice with these peptides protected $83 \%$ of the animals against the development of spontaneous HER2/neu over-expressing mammary tumors. The same group constructed two chimeric peptides, MVF HER2 (aa 316-339) and MVF HER2 (aa 485-503), which included one of the previously identified HER2 B-cell epitopes linked to a promiscuous 4 aa T-cell epitope (aa 288-302) from the measles virus fusion protein (MVF). Immunization of rabbits with these two candidate vaccines induced a specific humoral response against the peptide and also against the HER2 protein. In addition, sera from these rabbits inhibited growth of HER2 over-expressing BT474 breast cancer cells in vitro [77]. This study also showed that the combination of two chimeric vaccines (multi-epitope vaccine) was more efficient than a single vaccine and that the multi-epitope vaccine, in association with IL-12, significantly decreased the number of lung metastases induced by transplantation of syngeneic HER2 over-expressing tumor cells in BALB/c mice [77].

Another chimeric vaccine in which the same MVF T-cell epitope (aa 288-302) is combined with the HER2 B-cell epitope (aa 597-626) that corresponds to the binding site of trastuzumab on HER2 (aa 563-626) [78] elicited anti-HER2 Abs able to act through ADCC [79]. Similar results were obtained by Riemer et al. [80] with peptides selected by phage display. They identified three B-cell epitopes specific to HER2 ECD that induced anti-HER2 humoral response associated with anti-tumor activity in vitro [81]. More recently, these three peptides were combined with IL-12 in a multi-epitope vaccine formulation that protected $60 \%$ of immunized mice from developing spontaneous HER2/neu over-expressing mammary tumors [82]. This anti-tumor effect was associated in protected animals with the establishment of a Th1-type immune response and secretion of IFN $\gamma$ as well as high levels of anti-HER2 IgGs [82].

\section{Clinical work}

Finally, peptides that can induce anti-HER2 cellular and humoral immune responses have been identified in 
HLA-A24-positive patients with breast cancer [83]. Serum IgGs specific for these HER2 peptides (aa 342-350), (aa 485-493) and (aa 553-561) were detected in 47, 24 and $24 \%$ of patients, respectively. Moreover, these patients' PBMCs specifically lysed HLA-A24-positive tumor cells that over-express HER2. These results could lead to new peptide-based anti-HER2 vaccines to target the sub-population of patients who express the A24 allele of the HLA molecule. In addition, this type of vaccine would in theory be more effective in terms of clinical benefits because it can induce both cellular and humoral immune responses.

Potential limitation of using MHC class I-restricted peptides as vaccines

Major histocompatibility molecules (MHC) are involved in presentation of peptide antigens for recognition by the immune system. Recent progress in the understanding of the generation of peptides derived from intracellular proteins and their presentation at the cell surface in the context of MHC class I and class II alleles have led to the identification of several tumor antigens that are recognized by tumor-specific $\mathrm{T}$ cells. Moreover, it has been shown that oncogenes, such as c-Ras and c-Myc, down-regulate MHC class I surface expression [84, 85]. This phenomenon results in an escape from immuno-surveillance and could be associated with a metastatic phenotype. Similarly, HER2 expression induces down-regulation of MHC class I antigens that is associated with several defects in the antigen-processing pathway, thus impairing the ability to produce and display MHC class I peptide ligands to specific CTLs [86, 87]. Recently, Vertuani et al., 2009 [88], using the HHD mouse transgenic strain, showed that in vivo HER2-mediated down-regulation of both MHC class I and antigen-processing machinery (APM) components leads to impaired processing and presentation of the human leukocyte antigen (HLA)-A2 peptide complex, thus preventing tumor recognition by specific CTLs. As defective MHC class I presentation may be a common characteristic of HER2-expressing tumors, it underlines the importance of designing vaccines that target HER2 to induce an integrated immune response, which is composed of CTLs, antibodies and $\mathrm{CD} 4^{+} \mathrm{T}$ cells, to overcome HER-2-induced tumor resistance to specific $\mathrm{T}$-cell effector mechanisms.

\section{Protein-based vaccines}

Four clinical trials exploring this concept have been conducted using protein-based vaccines. One of them, a phase I clinical trial was conducted in 29 patients with HER2 over-expressing stage II, III or IV breast or ovarian cancer in remission using HER2 ICD (aa 676-1255) as an adjuvant vaccine [56]. The vaccine was injected intradermally at three different doses $(25,150$ and $900 \mu \mathrm{g})$ in combination with $100 \mu \mathrm{g}$ of GM-CSF once a month for 6 months. T-cell response specific to HER2 ICD was observed in $89 \%$ of immunized patients and $82 \%$ developed anti-HER2 IgGs. More than half of these patients maintained a cellular immunity of 9-12 months after completion of immunization. Although the injected doses theoretically did not predict the magnitude of the immune response, the authors nevertheless observed that patients who received the highest dose developed more rapidly antiHER2 immunity [56].

Other clinical studies have been conducted with dHER2, another anti-HER2 protein-based vaccine, made of the HER2 ECD and a portion of ICD (Table 2). Limentani et al., evaluated this vaccine in 15 patients with breast cancer and showed that Abs specific to HER2 ECD and ICD developed after four immunizations [89]. The complete results including the long-term benefit of this vaccine have not been published yet.

Another group used CHP-HER2, a protein-based vaccine composed of a truncated HER2 protein (aa 1-146) complexed to a delivery system consisting of cholesteryl pullulan nanogels (CHP). In the first clinical trial (Table 2), nine patients were immunized subcutaneously with $300 \mu \mathrm{g}$ of CHP-HER2 twice a week for 3 weeks, followed by boost injections. The vaccine was well tolerated and induced $\mathrm{CD}^{+}{ }^{+} \mathrm{T}$ and/or $\mathrm{CD}^{+}{ }^{+} \mathrm{T}$-cellular responses specific to the truncated HER2 protein [90]. In the second clinical trial, nine patients received the vaccine alone for the first our immunizations and then in combination with the adjuvant GM-CSF or OK-432. Six other patients received CHP-HER2 in combination with GM-CSF from the beginning of the vaccination schedule. The authors reported that 14 patients developed IgG specific to the truncated HER2 protein. However, none of them developed Abs that recognized the HER2 antigen expressed in its native form at the surface of tumor cells [91].

\section{Anti-idiotypic antibodies}

The use of anti-Id Abs mimicking HER2 for the treatment of breast cancer is very preliminary and still at the stage of establishing the proof of concept in preclinical models.

Baral et al. [92] immunized C57Bl/6 mice with the mouse anti-Id mAb 520C9-6b, which mimics an epitope of the human HER2 antigen, and reported that such immunization could induce anti-HER2 Abs.

More recently, the same group developed and characterized 6D12, another murine anti-Id mAb selected following immunization of mice with the anti-HER2 $\mathrm{mAb}$ 4D5 (the murine form of trastuzumab). Immunization of 
C57B1/6 mice with 6D12 in combination with the vaccine adjuvant QS21 stimulated 6D12- and HER2-specific humoral responses. Sera from immunized mice could lyse HER2 over-expressing tumor cells through ADCC. In addition, 6D12-immunized mice were protected against syngeneic challenge by HER2 over-expressing tumor cells, in contrast to non-immunized mice or mice challenged with the same tumor cell line which does not express HER2 [93, 94]. Very recently, Saha et al. evaluated the vaccine potential of 6D12-pulsed DCs in tolerant transgenic mice. Immunization with this vaccine resulted in the induction of HER2-specific humoral and cellular immune responses and protection against tumors expressing HER2 [95].

In our laboratory, we selected by phage display and characterized two human anti-Id scFv fragments, 40 and 69, which mimic the human HER2 antigen and can induce humoral anti-HER2 response in BALB/c mice [96]. More recently, we selected by phage display and characterized 1HE, a llama anti-Id single domain antibody (sdAb), which closely mimics human HER2 [97]. We also demonstrated that sera from 1HE-immunized BALB/c mice contain antiHER2 antibodies, which inhibit viability of HER2-positive cancer cells in vitro [97].

\section{Combination strategies}

Tumor cells display an altered repertoire of $\mathrm{MHC}$-associated peptides that can lead to the activation of immune cells capable of eliminating transformed cells. Under the pressure of the immune system, both the tumor and its microenvironment are modified and immune-resistant tumor variants are selected, thus initiating the process of cancer immuno-editing. This impairs not only the hostgenerated immuno-surveillance, but also leads to mechanisms of resistance to targeted immunotherapy in general and trastuzumab in particular. For this reason, combinatorial targeting is likely to be the next step in the treatment of HER2-positive breast cancer. Indeed, future challenges in cancer vaccines rely on "second generation" immunotherapy approaches (1) capable of initiating tumor-specific immunity, (2) that have the ability to recruit effector immune cells within the tumor site and (3) that lead to the preservation of the immune cell functionality within the tumor microenvironment by subverting specific tumor escape mechanisms [98].

Combination with standard therapies

\section{Chemotherapy}

One possible means of intervention is to induce a strong local inflammatory response by recruiting cytokines (IFN- $\gamma$,
TNF, IL-1) [99, 100]. For instance, recent findings suggest that cytotoxic chemotherapy, which targets dividing cells such as tumor cells and lymphocytes, and although administered systemically, acts locally and can improve the effects of immunotherapy [101-105]. Specifically, chemotherapy has been shown to be associated with tissue necrosis leading to an activation of immune cells and thus facilitating tumor antigen cross-presentation and crosspriming as well as lympho-depletion (i.e., elimination of regulatory $\mathrm{T}$ cells and of poorly functional anti-tumor $\mathrm{T}$ cells). Preclinical models [106] have already shown that trastuzumab and many chemotherapeutic agents, including taxanes or capecitabine, display synergistic anti-tumor activity. The combination of immunotherapy with cyclophosphamide has been largely studied in several tumor settings in humans [101]. The effect of cyclophosphamide is best appreciated at low dose when it acts as an immunostimulator via the elimination and the inactivation of $\mathrm{T}$ regs [105]. Recently, Emens et al. [107] showed that an allogeneic GM-CSF-secreting breast tumor vaccine is safe and bioactive when given alone or in sequential treatment with low-dose cyclophosphamide and doxorubicin. A larger trial to test the safety and efficacy of vaccine and the optimal chemotherapy dose combination is currently being designed. A combination of anti-HER2 agents and chemotherapy is currently the most frequently used strategy in the clinic.

\section{Hormonotherapy}

The combination of an HER2 targeting agent with endocrine treatments, for example letrozole [108], could be of some value, but, until now, this strategy has not provided conclusive results in the clinic.

\section{Radiotherapy}

Radiotherapy has been described as exerting immunomodulatory activity on a mouse adenocarcinoma cell line by up-regulating MHC class I expression and is efficient in enhancing adoptive tumor immunotherapy in mice with subcutaneous colon adenocarcinoma [109] or fibrosarcoma [110]. Radiotherapy has also proved useful in facilitating tumor antigen presentation in prostate cancer patients [111]. However, in the specific setting of anti-HER2 vaccines, no data are presently available to support this combination.

Combination with trastuzumab

Combining tumor vaccines with therapeutic monoclonal antibodies is another promising avenue for combination immunotherapy. Recently, it was anticipated that anti-HER2 
vaccines could be incorporated into already validated adjuvant treatments such as those with trastuzumab [73, 112]. These results represent the first clinical evidence of the potential benefits of minimal toxicity that may be derived from combination immunotherapy. Anti-HER2 vaccination may be suitable after trastuzumab treatment to try to further reduce the risk of recurrence, though trastuzumab alone in the adjuvant setting appears to prevent about $50 \%$ of recurrences in the population initially at high risk. It is in this context that a vaccine strategy may be useful as it could favor long-term immune surveillance, thus avoiding or delaying the onset of recurrence. Recently, Benavides et al. [72] have demonstrated that in a subset of patients with strongly HER2-positive cancers (IHC: $3+$ ), the combination of trastuzumab followed by vaccination with the E75 peptide seemed safe and immunologically beneficial. Similar results were reported by Disis et al. [112] with another anti-HER2 peptide-based vaccine, which was administered in combination with trastuzumab. Although they need to be confirmed, these findings suggest that combination therapy with trastuzumab and anti-HER2 vaccines has an immunological benefit; on the other hand, the clinical benefit of this association has not been proved yet. In this context, Coveler et al. [113] have recently showed that the administration of trastuzumab, biphosphanates and hormonal therapy concurrently with a cancer vaccine have no impact on either the generation or the magnitude of vaccine-induced immunity.

\section{Combination with lapatinib}

Very recently, Morse et al. [114] demonstrated in vivo that the combination of a recombinant adenoviral vector that expresses kinase-inactive HER2 (Ad-HER2-ki) and lapatinib (an oral dual receptor tyrosine kinase inhibitor that targets both HER1 and HER2 receptors) caused significant inhibition of HER2 signaling in vitro and higher anti-tumor efficacy in vivo in a mouse model than the vaccine alone.

Acting on defined receptors or enzymes

The major goal of anti-cancer vaccines is to counteract tumor-derived immunosuppression by specifically eliminating the mediators of immunosuppression. This can be achieved by acting on enzymes that are involved in the generation of immunomodulators, such as indoleamine 2,3dioxygenase (IDO) (which is produced by dendritic cells [115] and by many tumor cells) [116], PGE-2 [117] and VEGF that can act both as immunosuppressant and as angiogenic factor [118]. For instance, VEGF activity can be blocked by bevacizumab, a humanized anti-VEGF mAb widely used in the clinics [119]. TGF- $\beta$ inhibition could also improve tumor immunotherapy [120]. Fas and Trail apoptosis-related receptors could also constitute targets of immuno-intervention [121]. Death receptors are now one of the most attractive therapeutic targets in cancer, particularly for antibody-based therapy. The potential therapeutic utility of agonistic antibodies could possibly be extended when combined with additional strategies to further engage the cellular immune response [122]. Indeed, Stagg et al. [123] have demonstrated that antibodies that target the TRAIL receptor-2 and HER2 synergize in vivo and induce an anti-tumor immune response.

The second axis of combined intervention concerns (1) the direct elimination of the mediators of immunosuppression, such as the T-regulatory cells (Tregs:CD4 ${ }^{+}$ $\mathrm{CD}_{25}{ }^{+}$), which control key aspects of immunological tolerance to self-antigens, and (2) the negative regulation of T-cell activation and function. This can be achieved by several means including (1) specific mAbs against co-stimulatory receptors, such as CTLA-4 (CD152), (2) the recombinant IL-2-diphtheria toxin fusion protein also called ONTAK (that specifically targets CD25+ Tregs) or (3) inhibition of the immunosuppressive function of myeloid-derived suppressor cells (MDSC). Clinical trials using anti-CTLA4 antibodies have shown promising results in cancer patients previously vaccinated with GMCSF-expressing tumor vaccines [124, 125]. The antiCTLA4 antibody Tremelimumab (Pfizer) is currently evaluated in a clinical phase I/II trial in solid tumors. Monoclonal antibodies specific to other co-stimulatory receptors, such as $\mathrm{B} 7.1$ (CD80) or CD40, could also be considered for a combination strategy. Tregs are characterized by the expression of CD25, the high affinity receptor for IL2 [126]. Therefore, targeting CD25 with mAbs might represent an interesting but not optimal strategy due the long half-life of the antibody. ONTAK, which on the other hand has a very short half-life, was largely evaluated in the clinic in several human cancers with contrasting results probably due to the different treatment schedules of administration that seems to be more effective when short [98].

Inhibition of the immunosuppressive function of MDSC can also be achieved directly or indirectly by blockade of their function via enzymes involved in the catabolism of arginine (i.e., iNOS and arginase) [127].

Finally, the use of bi- or trifunctional antibodies that bear immunostimulating and anti-neoplastic activities is of real interest. As an example, ertumaxomab is a mouse monoclonal antibody with two antigen-recognition sites: one for CD3, which is expressed on mature T cells, and one for HER2. Ertumaxomab (Trion Pharma) selectively crosslinks tumor and immune cells resulting in the recruitment of cytotoxic $\mathrm{T}$ cells to the $\mathrm{T}$ cell/tumor cell aggregate [128]. This antibody is currently evaluated in a clinical phase II trial in breast cancer. 


\section{Other strategies}

Another promising method is the use of Listeria monocytogenes as a vaccine vector to treat cancers that express HER2 [30]. As a live bacterium, L. monocytogenes can stimulate strong innate and adaptive immune responses without the need for immuno-adjuvants. This Listeriadelivered vaccine may help overcome immune tolerance, leading to an effective therapeutic vaccine.

\section{Conclusion}

The antigens used in anti-HER2 vaccine strategies can be based either on HER2-positive cells or HER2-specific molecules (DNA, peptides, proteins or anti-idiotypic Abs). Although direct comparison of vaccine formulations in preclinical studies is very important to identify the more effective vaccine formulations for clinical trials, very little information is currently available. The theoretical advantages and disadvantages of each vaccination strategy have been summarized in Table 1. At present, protein- and peptide-based vaccines are the more advanced in terms of clinical development. HER2-specific vaccines, which are now in clinic trials, are presented in Table 2. For instance, E75 is currently in phase III clinical trials. However, this type of vaccine is restricted to HLA-A2-positive patients and generally elicits either humoral or cellular immune response. In contrast, vaccines based on recombinant HER2 are immunogenic across all HLA types, can elicit immunity in the majority of the patients on vaccination, stimulate both tumor-specific cellular and humoral immunity, and will result in the development of immunologic memory [56]. Anti-Id Abs, although still in the early stages of clinical development, also offers the advantage of targeting all patients (regardless of the HLA type). Elicitation of a cellular and/or humoral immunity is sometimes associated with biological effects. For example, in the study by Czerniecki et al. [45], a DC-based vaccine was used before surgical resection to assess the effects of the early immunotherapeutic targeting of HER2 in ductal carcinoma in situ (DCIS). The vaccinated subjects showed high rates of peptide-specific sensitization in both CD4 and CD8 T cells with peri-tumoral lymphocytic accumulation ( $\mathrm{T}$ and $\mathrm{B}$ lymphocytes) and induction of complement-dependent tumor-lytic antibodies associated in half of the cases with measurable reduction in the residual DCIS, suggesting an active process of immuno-editing in HER2-expressing tumor cells.

Cancer vaccines are developed to specifically target only tumor cells while preserving normal tissues from a nonspecific toxicity. So far, the data from clinical trials have shown that cancer vaccines induce low toxicity. This represents a major advantage over conventional therapies such as chemotherapy or radiotherapy. Particularly, the potential risk of developing an auto-immune disease using cancer vaccines has not been reported in clinical trials conducted so far. However, Jacob et al. [55] have shown that tumor regression in mice following anti-HER2 DNA vaccination and Treg depletion can exacerbate autoimmunity, which warrants close monitoring during immunotherapy trials. Indeed, it must be kept in mind that the risk of cardiotoxicity related to treatment with trastuzumab of patients with HER2-positive breast cancer is real, but low. If the risk linked to the use of vaccines were in the same range of magnitude (very low percentage of patients), the current data from vaccine clinical trials would not be able to bring it to light due to the limited number of enrolled subjects. In addition, anti-HER2 vaccines present the potential disadvantage that in the case of interruption of the vaccination scheme due to important toxicity linked to the HER2 targeting, these effects would persist, whereas trastuzumab cardiotoxicity is generally reversible at the end of administrations of $\mathrm{Ab}$. Performing extensive clinical toxicology and preclinical studies remains thus essential.

Although anti-HER2 vaccines can induce a specific immune response, the clinical benefits observed remain questionable. Several hypotheses have been proposed to explain these negative results: (1) deleterious impact on the immune system of treatments such as chemotherapy and radiotherapy prior to vaccination, (2) the difficulty in breaking the immune tolerance against the HER2 antigen, (3) the ability of tumors to escape the immune system and (4) the extremely advanced stage of disease of patients chosen for immunization. On the other hand, it is also important to keep in mind that many vaccine trials have targeted populations of patients in the adjuvant setting, who have a minimal tumor mass, and in whom, as a consequence, it is more difficult to evaluate the extent of the clinical benefits of such a therapy.

To validate a vaccination strategy, it is thus imperative to define the population who is most likely to benefit from the vaccine by taking into account the current standard therapies used for these patients and to combine them with the vaccine.

Future clinical trials should therefore target populations with an increased risk of relapse, e.g., patients with nodepositive HER2 over-expressing tumors. Within this population, such trials should assess whether increased levels of immune response against the target antigen is a predictive marker of clinical benefit. Other critical points to be investigate in future vaccination trials include the absence of clinical toxicity (including cardiac toxicity), optimal doses, immunization schedules, routes of injection, duration of immunization and boost doses to induce optimal primary and memory immune responses. 
For the development of effective vaccination strategies, the challenge remains to determine (1) molecular markers predictive of the response to the vaccine, (2) the best therapeutic schedule and (3) the best vaccine adjuvant capable of generating the most efficient immune response.

Finally, the development of a new generation of immunotherapy protocols relies on the identification of ways to interfere with the negative regulation of immune response. Several approaches have been proposed, including vaccines coupled to inhibitory molecules, monoclonal antibodies, bacteria or bacterial compounds, radiotherapy and chemotherapy. The timing and doses of administration of combined protocols and the correlation data on the immunological/clinical response are of crucial importance for the success of these therapies.

Open Access This article is distributed under the terms of the Creative Commons Attribution Noncommercial License which permits any noncommercial use, distribution, and reproduction in any medium, provided the original author(s) and source are credited.

\section{References}

1. Slichenmyer WJ, Fry DW (2001) Anticancer therapy targeting the erbB family of receptor tyrosine kinases. Semin Oncol 28:67-79

2. Schmidt M, Lewark B, Kohlschmidt N et al (2005) Long-term prognostic significance of HER-2/neu in untreated node-negative breast cancer depends on the method of testing. Breast Cancer Res 7:R256-266

3. Martín M, Rodríguez-Lescure A, Ruiz A et al (2008) Randomized phase 3 trial of fluorouracil, epirubicin, and cyclophosphamide alone or followed by paclitaxel for early breast cancer. J Natl Cancer Inst 100:805-814

4. Ross JS, Fletcher JA (1998) The HER-2/neu oncogene in breast cancer: prognostic factor, predictive factor, and target for therapy. Oncologist 3:237-252

5. Peoples GE, Goedegebuure PS, Smith R, Linehan DC, Yoshino I, Eberlein TJ (1995) Breast and ovarian cancer-specific cytotoxic $\mathrm{T}$ lymphocytes recognize the same HER2/neu-derived peptide. Proc Natl Acad Sci USA 92:432-436

6. Slamon DJ, Leyland-Jones B, Shak S et al (2001) Use of chemotherapy plus a monoclonal antibody against HER2 for metastatic breast cancer that overexpresses HER2. N Engl J Med 344:783-792

7. Nahta R, Esteva FJ (2006) Herceptin: mechanisms of action and resistance. Cancer Lett 232:123-138

8. Berns K, Horlings HM, Hennessy BT et al (2007) A functional genetic approach identifies the PI3K pathway as a major determinant of trastuzumab resistance in breast cancer. Cancer Cell 12:395-402

9. Cobleigh MA, Vogel CL, Tripathy D et al (1999) Multinational study of the efficacy and safety of humanized anti-HER2 monoclonal antibody in women who have HER2-overexpressing metastatic breast cancer that has progressed after chemotherapy for metastatic disease. J Clin Oncol 17:2639-2648

10. Bengala C, Zamagni C, Pedrazzoli P et al (2006) Cardiac toxicity of trastuzumab in metastatic breast cancer patients previously treated with high-dose chemotherapy: a retrospective study. Br J Cancer 94:1016-1020
11. Disis ML, Calenoff E, McLaughlin G et al (1994) Existent T-cell and antibody immunity to HER-2/neu protein in patients with breast cancer. Cancer Res 54:16-20

12. Fisk B, Blevins TL, Wharton JT, Ioannides CG (1995) Identification of an immunodominant peptide of HER-2/neu protooncogene recognized by ovarian tumor-specific cytotoxic $\mathrm{T}$ lymphocyte lines. J Exp Med 181:2109-2117

13. Disis ML, Bernhard H, Shiota FM et al (1996) Granulocytemacrophage colony-stimulating factor: an effective adjuvant for protein and peptide-based vaccines. Blood 88:202-210

14. Huber CH, Wölfel $\mathrm{T}$ (2004) Immunotherapy of cancer: from vision to standard clinical practice. J Cancer Res Clin Oncol 130:367-374

15. Burnet F (1957) Cancer: a biological approach. Br Med J 1:841847

16. Fendly BM, Winget M, Hudziak RM, Lipari MT, Napier MA, Ullrich A (1990) Characterization of murine monoclonal antibodies reactive to either the human epidermal growth factor receptor or HER2/neu gene product. Cancer Res 50:1550-1558

17. Pegram MD, Pauletti G, Slamon DJ (1998) HER-2/neu as a predictive marker of response to breast cancer therapy. Breast Cancer Res Treat 52:65-77

18. Winer EP, Burstein HJ (2001) New combinations with herceptin in metastatic breast cancer. Oncology 61(Suppl 2):50-57

19. Rilke F, Colnaghi MI, Cascinelli N et al (1991) Prognostic significance of HER-2/neu expression in breast cancer and its relationship to other prognostic factors. Int J Cancer 49:44-49

20. Disis ML, Shiota FM, Cheever MA (1998) Human HER-2/neu protein immunization circumvents tolerance to rat neu: a vaccine strategy for 'self' tumour antigens. Immunology 93:192-199

21. Nanda NK, Sercarz EE (1995) Induction of anti-self-immunity to cure cancer. Cell 82:13-17

22. Dakappagari NK, Douglas DB, Triozzi PL, Stevens VC, Kaumaya PT (2000) Prevention of mammary tumors with a chimeric HER-2 B-cell epitope peptide vaccine. Cancer Res 60:37823789

23. Disis ML, Gralow JR, Bernhard H, Hand SL, Rubin WD, Cheever MA (1996) Peptide-based, but not whole protein, vaccines elicit immunity to HER-2/neu, oncogenic self-protein. J Immunol 156:3151-3158

24. Disis ML, Gooley TA, Rinn K et al (2002) Generation of T-cell immunity to the HER-2/neu protein after active immunization with HER-2/neu peptide-based vaccines. J Clin Oncol 20:26242632

25. Concetti A, Amici A, Petrelli C, Tibaldi A, Provinciali M, Venanzi FM (1996) Autoantibody to p185erbB2/neu oncoprotein by vaccination with xenogenic DNA. Cancer Immunol Immunother 43:307-315

26. Di Carlo E, Rovero S, Boggio K et al (2001) Inhibition of mammary carcinogenesis by systemic interleukin 12 or p185neu DNA vaccination in Her-2/neu transgenic BALB/c mice. Clin Cancer Res 7:830s-837s

27. Pilon SA, Piechocki MP, Wei WZ (2001) Vaccination with cytoplasmic ErbB-2 DNA protects mice from mammary tumor growth without anti-ErbB-2 antibody. J Immunol 167:3201-3206

28. Curigliano G, Spitaleri G, Pietri E et al (2006) Breast cancer vaccines: a clinical reality or fairy tale? Ann Oncol 17:750-762

29. Lollini P, De Giovanni C, Pannellini T, Cavallo F, Forni G, Nanni P (2005) Cancer immunoprevention. Future Oncol $1: 57-66$

30. Seavey MM, Pan Z, Maciag PC et al (2009) A novel human Her-2/neu chimeric molecule expressed by Listeria monocytogenes can elicit potent HLA-A2 restricted CD8-positive T cell responses and impact the growth and spread of Her-2/neupositive breast tumors. Clin Cancer Res 15:924-932 
31. Holmes JP, Benavides LC, Gates JD et al (2008) Results of the first phase I clinical trial of the novel II-key hybrid preventive HER-2/neu peptide (AE37) vaccine. J Clin Oncol 26:3426-3433

32. Hodi FS (2007) Cytotoxic T-lymphocyte-associated antigen-4. Clin Cancer Res 13:5238-5242

33. Dols A, Smith JW, Meijer SL et al (2003) Vaccination of women with metastatic breast cancer, using a costimulatory gene (CD80)-modified, HLA-A2-matched, allogeneic, breast cancer cell line: clinical and immunological results. Hum Gene Ther 14:1117-1123

34. Dols A, Meijer SL, Hu H et al (2003) Identification of tumorspecific antibodies in patients with breast cancer vaccinated with gene-modified allogeneic tumor cells. J Immunother 26:163-170

35. Kim PS, Armstrong TD, Song $\mathrm{H}$ et al (2008) Antibody association with HER-2/neu-targeted vaccine enhances CD8 $\mathrm{T}$ cell responses in mice through $\mathrm{Fc}$-mediated activation of DCs. J Clin Invest 118:1700-1711

36. Park JW, Melisko ME, Esserman LJ, Jones LA, Wollan JB, Sims R (2007) Treatment with autologous antigen-presenting cells activated with the HER-2 based antigen Lapuleucel-T: results of a phase I study in immunologic and clinical activity in HER-2 overexpressing breast cancer. J Clin Oncol 25:36803687

37. Sakai Y, Morrison BJ, Burke JD et al (2004) Vaccination by genetically modified dendritic cells expressing a truncated neu oncogene prevents development of breast cancer in transgenic mice. Cancer Res 64:8022-8028

38. Chen Y, Emtage P, Zhu Q et al (2001) Induction of ErbB-2/neuspecific protective and therapeutic antitumor immunity using genetically modified dendritic cells: enhanced efficacy by cotransduction of gene encoding IL-12. Gene Ther 8:316-323

39. Chen Z, Huang H, Chang T et al (2002) Enhanced HER-2/neuspecific antitumor immunity by cotransduction of mouse dendritic cells with two genes encoding HER-2/neu and alpha tumor necrosis factor. Cancer Gene Ther 9:778-786

40. Campbell M, Qu S, Wells S, Sugandha H, Jensen RA (2003) An adenoviral vector containing an arg-gly-asp (RGD) motif in the fiber knob enhances protein product levels from transgenes refractory to expression. Cancer Gene Ther 10:559-570

41. Sas S, Chan T, Sami A, El-Gayed A, Xiang J (2008) Vaccination of fiber-modified adenovirus-transfected dendritic cells to express HER-2/neu stimulates efficient HER-2/neu-specific humoral and CTL responses and reduces breast carcinogenesis in transgenic mice. Cancer Gene Ther 15:655-666

42. Chan T, Sami A, El-Gayed A, Guo X, Xiang J (2006) HER-2/ neu-gene engineered dendritic cell vaccine stimulates stronger HER-2/neu-specific immune responses compared to DNA vaccination. Gene Ther 13:1391-1402

43. Viehl CT, Becker-Hapak M, Lewis JS et al (2005) A tat fusion protein-based tumor vaccine for breast cancer. Ann Surg Oncol 12:517-525

44. Brossart P, Wirths S, Stuhler G, Reichardt VL, Kanz L, Brugger W (2000) Induction of cytotoxic T-lymphocyte responses in vivo after vaccinations with peptide-pulsed dendritic cells. Blood 96:3102-3108

45. Czerniecki BJ, Koski GK, Koldovsky U et al (2007) Targeting HER-2/neu in early breast cancer development using dendritic cells with staged interleukin-12 burst secretion. Cancer Res 67:1842-1852

46. Wei WZ, Shi WP, Galy A et al (1999) Protection against mammary tumor growth by vaccination with full-length, modified human ErbB-2 DNA. Int J Cancer 81:748-754

47. Piechocki MP, Pilon SA, Wei WZ (2001) Complementary antitumor immunity induced by plasmid DNA encoding secreted and cytoplasmic human ErbB-2. J Immunol 167:3367-3374
48. Wei W, Jacob JB, Zielinski JF et al (2005) Concurrent induction of antitumor immunity and autoimmune thyroiditis in $\mathrm{CD}^{+}$ $\mathrm{CD}_{25}{ }^{+}$regulatory $\mathrm{T}$ cell-depleted mice. Cancer Res 65:84718478

49. Jacob J, Radkevich O, Forni G et al (2006) Activity of DNA vaccines encoding self or heterologous Her-2/neu in Her-2 or neu transgenic mice. Cell Immunol 240:96-106

50. Jacob JB, Kong YM, Meroueh C et al (2007) Control of Her-2 tumor immunity and thyroid autoimmunity by MHC and regulatory T cells. Cancer Res 67:7020-7027

51. Rovero S, Amici A, Di Carlo E et al (2000) DNA vaccination against rat her-2/Neu p185 more effectively inhibits carcinogenesis than transplantable carcinomas in transgenic BALB/c mice. J Immunol 165:5133-5142

52. Gallo P, Dharmapuri S, Nuzzo M et al (2005) Xenogeneic immunization in mice using HER2 DNA delivered by an adenoviral vector. Int J Cancer 113:67-77

53. Aurisicchio L, Peruzzi D, Conforti A et al (2009) Treatment of mammary carcinomas in HER-2 transgenic mice through combination of genetic vaccine and an agonist of Toll-like receptor 9. Clin Cancer Res 15:1575-1584

54. Radkevich-Brown O, Jacob J, Kershaw M, Wei W (2009) Genetic regulation of the response to Her-2 DNA vaccination in human Her-2 transgenic mice. Cancer Res 69:212-218

55. Jacob JB, Kong YM, Nalbantoglu I, Snower DP, Wei W (2009) Tumor regression following DNA vaccination and regulatory $\mathrm{T}$ cell depletion in neu transgenic mice leads to an increased risk for autoimmunity. J Immunol 182:5873-5881

56. Disis ML, Schiffman K, Guthrie K et al (2004) Effect of dose on immune response in patients vaccinated with an her-2/neu intracellular domain protein-based vaccine. J Clin Oncol 22:1916-1925

57. Disis ML, Goodell V, Schiffman K, Knutson KL (2004) Humoral epitope-spreading following immunization with a HER-2/neu peptide based vaccine in cancer patients. J Clin Immunol 24:571-578

58. Knutson KL, Schiffman K, Disis ML (2001) Immunization with a HER-2/neu helper peptide vaccine generates HER-2/neu CD8 T-cell immunity in cancer patients. J Clin Invest 107:477-484

59. Butterfield LH, Ribas A, Dissette VB et al (2003) Determinant spreading associated with clinical response in dendritic cellbased immunotherapy for malignant melanoma. Clin Cancer Res 9:998-1008

60. Disis ML, Strickler J, Wallace D et al. (2008) Cellular immune parameters associated with improved long-term survival in advanced stage breast cancer patients after active immunization with a HER2-specific vaccine. ASCO Abstract 3015

61. Webster D, Waisman J, Macleod B et al. (2006) A phase I/II study of a HER2/neu (HER2) peptide vaccine plus concurrent trastuzumab. ASCO Abstract 2528

62. Mittendorf EA, Holmes JP, Ponniah S, Peoples GE (2008) The E75 HER2/neu peptide vaccine. Cancer Immunol Immunother 57:1511-1521

63. Lustgarten J, Theobald M, Labadie C et al (1997) Identification of Her-2/Neu CTL epitopes using double transgenic mice expressing HLA-A2.1 and human CD8. Hum Immunol 52:109118

64. Anderson BW, Peoples GE, Murray JL, Gillogly MA, Gershenson DM, Ioannides CG (2000) Peptide priming of cytolytic activity to HER-2 epitope 369-377 in healthy individuals. Clin Cancer Res 6:4192-4200

65. Knutson KL, Schiffman K, Cheever MA, Disis ML (2002) Immunization of cancer patients with a HER-2/neu, HLA-A2 peptide, p369-377, results in short-lived peptide-specific immunity. Clin Cancer Res 8:1014-1018 
66. Murray JL, Gillogly ME, Przepiorka D et al (2002) Toxicity, immunogenicity, and induction of E75-specific tumor-lytic CTLs by HER-2 peptide E75 (369-377) combined with granulocyte macrophage colony-stimulating factor in HLA-A2+ patients with metastatic breast and ovarian cancer. Clin Cancer Res 8:3407-3418

67. Zaks TZ, Rosenberg SA (1998) Immunization with a peptide epitope (p369-377) from HER-2/neu leads to peptide-specific cytotoxic $\mathrm{T}$ lymphocytes that fail to recognize HER-2/neu+ tumors. Cancer Res 58:4902-4908

68. Peoples GE, Gurney JM, Hueman MT et al (2005) Clinical trial results of a HER2/neu (E75) vaccine to prevent recurrence in high-risk breast cancer patients. J Clin Oncol 23:7536-7545

69. Peoples GE, Holmes JP, Hueman MT et al (2008) Combined clinical trial results of a HER2/neu (E75) vaccine for the prevention of recurrence in high-risk breast cancer patients: U.S. Military Cancer Institute Clinical Trials Group Study I-01 and I-02. Clin Cancer Res 14:797-803

70. Hueman MT, Stojadinovic A, Storrer CE et al (2006) Levels of circulating regulatory $\mathrm{CD} 4+\mathrm{CD} 25+\mathrm{T}$ cells are decreased in breast cancer patients after vaccination with a HER2/neu peptide (E75) and GM-CSF vaccine. Breast Cancer Res Treat 98:17-29

71. Shimizu J, Yamazaki S, Sakaguchi S (1999) Induction of tumor immunity by removing CD25+ CD4+ T cells: a common basis between tumor immunity and autoimmunity. J Immunol 163:5211-5218

72. Benavides LC, Gates JD, Carmichael MG et al (2009) The impact of HER2/neu expression level on response to the E75 vaccine: from U.S. Military Cancer Institute Clinical Trials Group Study I-01 and I-02. Clin Cancer Res 15:2895-2904

73. Mittendorf EA, Storrer CE, Shriver CD, Ponniah S, Peoples GE (2006) Investigating the combination of trastuzumab and HER2/ neu peptide vaccines for the treatment of breast cancer. Ann Surg Oncol 13:1085-1098

74. Mittendorf EA, Storrer CE, Foley RJ et al (2006) Evaluation of the HER2/neu-derived peptide GP2 for use in a peptide-based breast cancer vaccine trial. Cancer 106:2309-2317

75. Lekka E, Gritzapis AD, Perez SA et al (2010) Identification and characterization of a HER-2/neu epitope as a potential target for cancer immunotherapy. Cancer Immunol Immunother 59:715727

76. Yip YL, Smith G, Koch J, Dübel S, Ward RL (2001) Identification of epitope regions recognized by tumor inhibitory and stimulatory anti-ErbB-2 monoclonal antibodies: implications for vaccine design. J Immunol 166:5271-5278

77. Dakappagari NK, Pyles J, Parihar R, Carson WE, Young DC, Kaumaya PTP (2003) A chimeric multi-human epidermal growth factor receptor-2 B cell epitope peptide vaccine mediates superior antitumor responses. J Immunol 170:4242-4253

78. Cho H, Mason K, Ramyar KX et al (2003) Structure of the extracellular region of HER2 alone and in complex with the Herceptin Fab. Nature 421:756-760

79. Garrett JT, Rawale S, Allen SD et al (2007) Novel engineered trastuzumab conformational epitopes demonstrate in vitro and in vivo antitumor properties against HER-2/neu. J Immunol 178:7120-7131

80. Riemer AB, Klinger M, Wagner S et al (2004) Generation of Peptide mimics of the epitope recognized by trastuzumab on the oncogenic protein Her-2/neu. J Immunol 173:394-401

81. Jasinska J, Wagner S, Radauer C et al (2003) Inhibition of tumor cell growth by antibodies induced after vaccination with peptides derived from the extracellular domain of Her-2/neu. Int $\mathbf{J}$ Cancer 107:976-983

82. Wagner S, Jasinska J, Breiteneder H et al (2007) Delayed tumor onset and reduced tumor growth progression after immunization with a Her-2/neu multi-peptide vaccine and IL-12 in c-neu transgenic mice. Breast Cancer Res Treat 106:29-38

83. Azuma K, Shichijo S, Shomura H, Matsueda S, Fujii T, Itoh K (2004) Identification of HER2/neu-derived peptides capable of inducing both cellular and humoral immune responses in HLA-A24 positive breast cancer patients. Breast Cancer Res Treat 86:19-29

84. Seliger B, Harders C, Lohmann S et al (1998) Down-regulation of the MHC class I antigen-processing machinery after oncogenic transformation of murine fibroblasts. Eur J Immunol 28:122-133

85. Schrier PI, Versteeg R, Peltenburg LT, Plomp AC, van't Veer LJ LJ, Krüse-Wolters KM (1991) Sensitivity of melanoma cell lines to natural killer cells: a role for oncogene-modulated HLA class I expression? Semin Cancer Biol 2:73-83

86. Choudhury A, Charo J, Parapuram SK et al (2004) Small interfering RNA (siRNA) inhibits the expression of the Her2/ neu gene, upregulates HLA class I and induces apoptosis of Her2/neu positive tumor cell lines. Int J Cancer 108:71-77

87. Herrmann F, Lehr H, Drexler I et al (2004) HER-2/neu-mediated regulation of components of the MHC class I antigen-processing pathway. Cancer Res 64:215-220

88. Vertuani S, Triulzi C, Roos AK et al (2009) HER-2/neu mediated down-regulation of MHC class I antigen processing prevents CTL-mediated tumor recognition upon DNA vaccination in HLA-A2 transgenic mice. Cancer Immunol Immunother 58:653-664

89. Limentani S, Dorval T, White S et al. (2005) Phase I doseescalation trial of a recombinant HER2 vaccine in patients with stage II/III HER2+ breast cancer. ASCO Abstract 520

90. Kitano S, Kageyama S, Nagata Y et al (2006) HER2-specific $\mathrm{T}$-cell immune responses in patients vaccinated with truncated HER2 protein complexed with nanogels of cholesteryl pullulan. Clin Cancer Res 12:7397-7405

91. Kageyama S, Kitano S, Hirayama M et al (2008) Humoral immune responses in patients vaccinated with 1-146 HER2 protein complexed with cholesteryl pullulan nanogel. Cancer Sci 99:601-607

92. Baral R, Sherrat A, Das R, Foon KA, Bhattacharya-Chatterjee M (2001) Murine monoclonal anti-idiotypic antibody as a surrogate antigen for human Her-2/neu. Int J Cancer 92:88-95

93. Mohanty K, Saha A, Pal S et al (2007) Anti-tumor immunity induced by an anti-idiotype antibody mimicking human Her- $2 /$ neu. Breast Cancer Res Treat 104:1-11

94. Pal S, Saha A, Mohanty K et al (2007) Generation of Her-2/neu vaccine utilizing idiotypic network cascade. Cancer Biol Ther 6:1916-1925

95. Saha A, Chatterjee SK (2010) Dendritic cells pulsed with an anti-idiotype antibody mimicking Her-2/neu induced protective antitumor immunity in two lines of Her-2/neu transgenic mice. Cell Immunol. http://www.ncbi.nlm.nih.gov.gate2.inist.fr/ pubmed/20236626

96. Coelho $M$, Gauthier $P$, Pugnière $M$, Roquet $F$, Pèlegrin A, Navarro-Teulon I (2004) Isolation and characterisation of a human anti-idiotypic scFv used as a surrogate tumour antigen to elicit an anti-HER-2/neu humoral response in mice. Br J Cancer 90:2032-2041

97. Alvarez-Rueda N, Ladjemi MZ, Béhar G et al (2009) A llama single domain anti-idiotypic antibody mimicking HER2 as a vaccine: Immunogenicity and efficacy. Vaccine 27:4826-4833

98. Rescigno M, Avogadri F, Curigliano G (2007) Challenges and prospects of immunotherapy as cancer treatment. Biochim Biophys Acta 1776:108-123

99. Mantovani A, Sica A, Sozzani S, Allavena P, Vecchi A, Locati M (2004) The chemokine system in diverse forms of macrophage activation and polarization. Trends Immunol 25:677-686 
100. Kalinski P, Nakamura Y, Watchmaker P, Giermasz A, Muthuswamy R, Mailliard RB (2006) Helper roles of NK and $\mathrm{CD}^{+} \mathrm{T}$ cells in the induction of tumor immunity: polarized dendritic cells as cancer vaccines. Immunol Res 36:137-146

101. Nowak AK, Lake RA, Robinson BWS (2006) Combined chemoimmunotherapy of solid tumours: improving vaccines? Adv Drug Deliv Rev 58:975-990

102. Lake RA, Robinson BWS (2005) Immunotherapy and chemotherapy: a practical partnership. Nat Rev Cancer 5:397-405

103. Nowak AK, Lake RA, Marzo AL et al (2003) Induction of tumor cell apoptosis in vivo increases tumor antigen cross-presentation, cross-priming rather than cross-tolerizing host tumor-specific CD8 T cells. J Immunol 170:4905-4913

104. Rovere P, Vallinoto C, Bondanza A et al (1998) Bystander apoptosis triggers dendritic cell maturation and antigen-presenting function. J Immunol 161:4467-4471

105. Lutsiak MEC, Semnani RT, De Pascalis R, Kashmiri SVS, Schlom J, Sabzevari H (2005) Inhibition of CD4(+)25+ T regulatory cell function implicated in enhanced immune response by low-dose cyclophosphamide. Blood 105:2862-2868

106. Pegram M, Hsu S, Lewis G et al (1999) Inhibitory effects of combinations of HER-2/neu antibody and chemotherapeutic agents used for treatment of human breast cancers. Oncogene 18:2241-2251

107. Emens LA, Asquith JM, Leatherman JM et al (2009) Timed sequential treatment with cyclophosphamide, doxorubicin, and an allogeneic granulocyte-macrophage colony-stimulating factorsecreting breast tumor vaccine: a chemotherapy dose-ranging factorial study of safety and immune activation. J Clin Oncol 27:5911-5918

108. Ellis MJ, Coop A, Singh B et al (2001) Letrozole is more effective neoadjuvant endocrine therapy than tamoxifen for ErbB-1- and/or ErbB-2-positive, estrogen receptor-positive primary breast cancer: evidence from a phase III randomized trial. J Clin Oncol 19:3808-3816

109. Reits EA, Hodge JW, Herberts CA et al (2006) Radiation modulates the peptide repertoire, enhances MHC class I expression, and induces successful antitumor immunotherapy. J Exp Med 203:1259-1271

110. Zhang B, Li H, Guo L, Yan D, Liu J, Na Y (2007) Application of 64-slice helical CT in screening of coronary artery heart disease among apparently healthy people: preliminary experience. Zhonghua Yi Xue Za Zhi 87:556-558

111. Nesslinger NJ, Sahota RA, Stone B et al (2007) Standard treatments induce antigen-specific immune responses in prostate cancer. Clin Cancer Res 13:1493-1502

112. Disis ML, Wallace DR, Gooley TA et al (2009) Concurrent trastuzumab and HER2/neu-specific vaccination in patients with metastatic breast cancer. J Clin Oncol 27:4685-4692

113. Coveler AL, Goodell V, Webster DJ et al (2009) Common adjuvant breast cancer therapies do not inhibit cancer vaccine induced T cell immunity. Breast Cancer Res Treat 113:95-100
114. Morse MA, Wei J, Hartman Z et al. (2010) Synergism from combined immunologic and pharmacologic inhibition of HER2 in vivo. Int J Cancer http://www.ncbi.nlm.nih.gov.gate2.inist.fr/ pubmed/19856307

115. Munn DH, Sharma MD, Hou D et al (2004) Expression of indoleamine 2, 3-dioxygenase by plasmacytoid dendritic cells in tumor-draining lymph nodes. J Clin Invest 114:280-290

116. Friberg M, Jennings R, Alsarraj $M$ et al (2002) Indoleamine 2,3dioxygenase contributes to tumor cell evasion of $\mathrm{T}$ cell-mediated rejection. Int $\mathrm{J}$ Cancer 101:151-155

117. Kaliński P, Vieira PL, Schuitemaker JH, de Jong EC, Kapsenberg ML (2001) Prostaglandin E(2) is a selective inducer of interleukin-12 p40 (IL-12p40) production and an inhibitor of bioactive IL-12p70 heterodimer. Blood 97:3466-3469

118. Johnson BF, Clay TM, Hobeika AC, Lyerly HK, Morse MA (2007) Vascular endothelial growth factor and immunosuppression in cancer: current knowledge and potential for new therapy. Expert Opin Biol Ther 7:449-460

119. Pañares RL, Garcia AA (2007) Bevacizumab in the management of solid tumors. Expert Rev Anticancer Ther 7:433-445

120. Fakhrai H, Dorigo O, Shawler DL et al (1996) Eradication of established intracranial rat gliomas by transforming growth factor beta antisense gene therapy. Proc Natl Acad Sci USA 93:2909-2914

121. Smyth MJ, Takeda K, Hayakawa Y, Peschon JJ, van den Brink MRM, Yagita H (2003) Nature's TRAIL-on a path to cancer immunotherapy. Immunity 18:1-6

122. Takeda K, Stagg J, Yagita H, Okumura K, Smyth MJ (2007) Targeting death-inducing receptors in cancer therapy. Oncogene 26:3745-3757

123. Stagg J, Sharkey J, Pommey S et al (2008) Antibodies targeted to TRAIL receptor-2 and ErbB-2 synergize in vivo and induce an antitumor immune response. Proc Natl Acad Sci USA 105:16254-16259

124. Hodi FS, Mihm MC, Soiffer RJ et al (2003) Biologic activity of cytotoxic $\mathrm{T}$ lymphocyte-associated antigen 4 antibody blockade in previously vaccinated metastatic melanoma and ovarian carcinoma patients. Proc Natl Acad Sci USA 100:4712-4717

125. Hodi FS, Butler M, Oble DA et al (2008) Immunologic and clinical effects of antibody blockade of cytotoxic T lymphocyteassociated antigen 4 in previously vaccinated cancer patients. Proc Natl Acad Sci USA 105:3005-3010

126. Curiel TJ (2007) Tregs and rethinking cancer immunotherapy. J Clin Invest 117:1167-1174

127. Sica A, Bronte V (2007) Altered macrophage differentiation and immune dysfunction in tumor development. J Clin Invest 117:1155-1166

128. Kiewe P, Thiel E (2008) Ertumaxomab: a trifunctional antibody for breast cancer treatment. Expert Opin Investig Drugs 17:1553-1558 